\title{
Sustainable Intensification in Dryland Cropping Systems-Perspectives for Adaptions across the Western Siberian Grain Belt
}

\author{
Insa Kühling * (D), Shohrukh Atoev and Dieter Trautz \\ Faculty of Agricultural Sciences and Landscape Architecture, Working Group Sustainable Agro-Ecosystems, \\ Osnabrück University of Applied Sciences, 49090 Osnabrück, Germany; ashohrukh@gmail.com (S.A.); \\ d.trautz@hs-osnabrueck.de (D.T.) \\ * Correspondence: i.kuehling@hs-osnabrueck.de; Tel.: +49-541-969-5298
}

Received: 2 April 2018; Accepted: 26 April 2018; Published: 29 April 2018

\begin{abstract}
The Western Siberian grain belt is of global significance in terms of agricultural production as well as carbon sequestration and biodiversity preservation. Regional downscaling of general circulation models predict increasing drought risks and water scarcity for this area. Additionally, significant land-use changes took place in this region after the dissolution of the USSR and collapse of the state farm system: Land-use intensity in Western Siberia (Russian Federation) continuously decreased on grassland, whilst on cropland the intensity increased through recultivation of abandoned cropland and rising fertilizer inputs since 2003. Together, these changing conditions have led to challenges for sustainable agriculture in this semi-arid environment. For sustainable land management, strategies for adapted crop production systems are needed. In agronomic field trials, the potential of enhanced water use efficiency as contribution to a resilient agricultural system under changing climate conditions was evaluated and related to the common practice and regional research. In participatory on-farm trials, higher average soil water content $(+40 \%)$ in the top soil layer led to higher grain yield $\left(+0.4 \mathrm{t} \mathrm{ha}^{-1}\right)$ and protein yield $\left(+0.05 \mathrm{t} \mathrm{ha}^{-1}\right)$ under no-till compared to the common practice of conventional tillage. Despite this, regional research still promotes bare fallowing with beneficial effects only in the first harvest after fallow, whereas the potential of no-till was visible each year, even under above-average wet and cool growing conditions. In this case study from the Western Siberian grain belt, we depict a possible pathway to make cereal production in Western Siberia more sustainable. However, the approach of applied sustainable intensification by promoting no-till is related to the negative concomitant effect of increased herbicide applications. Due to the strict rejection of GMOs in Russian agriculture by the federal government, this is a great opportunity to maintain a large, pristine area of over 17 million $\mathrm{km}^{2}$ with a lower risk of glyphosate-dependent cropping systems.
\end{abstract}

Keywords: bare fallow; no-till; conservation agriculture; crop rotation; spring wheat; water use efficiency

\section{Introduction}

To feed the growing global population, future agricultural production needs to be more productive and stable while minimising environmental impacts [1]. The Western Siberian grain belt is of global significance in terms of agricultural production as well as carbon sequestration and biodiversity preservation. Regional downscaling of general circulation models predict increasing drought risks and water scarcity for this area [2,3]. Additionally, significant land use changes took place in this region after the dissolution of the USSR and collapse of the state farm system [4]. Land-use intensity in Western Siberia (Russian Federation) continuously decreased on grassland, whilst on cropland the 
intensity increased through recultivation of abandoned cropland and rising fertilizer inputs observed since 2003 [5]. Together, these changing conditions have led to challenges for sustainable agriculture in this semi-arid environment [6]. For sustainable land management practices, strategies for adapted crop production systems are needed.

Agricultural intensification in the past made marked increases in yields possible by a combination of breeding progress, mechanisation and the increased use of mineral fertilizers and agrochemicals. Various indicators for intensification are described, e.g., increased area under irrigation, use of nitrogen fertilizers or pesticide applications [7]. This had a remarkable environmental impact and made agricultural systems less efficient. Nevertheless, some researchers still promote a targeted use of fertilizers to close yield gaps [1,8]. In 2008, the Food and Agriculture Organization of the United Nations (FAO) stated that no technology should be excluded [9]. That includes the use of genetically modified organisms (GMO) as one possible pathway of intensification following the FAO.

Beyond agricultural production, global ecosystem services such as carbon sequestration, water cycling, biodiversity or global climate regulation are strongly influenced by the ecosystems of Western Siberia [10]. Therefore, the need for sustainable land management strategies for this area is not only of regional or national interest, but reflects global goals. Moreover, the strict rejection of GMO in Russian agriculture by the federal government is a great opportunity to maintain a large, pristine area of over 17 million $\mathrm{km}^{2}$ [11].

Within the interdisciplinary German-Russian research project 'SASCHA' [12], we evaluated in agronomic field trials the potential of enhanced water use efficiency as applied sustainable intensification and contribution to a resilient agricultural system under changing climate conditions [13]. In this paper we contrast and compare findings from the project field trials with those of common practice and regional research. This case study from the Western Siberian grain belt can serve as an example of applied sustainable intensification for the forest steppe zone of the Eurasian grain belt.

\section{Study Region}

The Western Siberian grain belt is located in the Asian part of Russia (Figure 1) and characterized by a continental climate with $395 \mathrm{~mm}$ mean annual precipitation (dry-subhumid) and an average temperature of $1.9^{\circ} \mathrm{C}$ (range from -44 to $+37^{\circ} \mathrm{C}$ ) [14].

Western Siberia has a relatively short history of agricultural land use $[15,16]$. Starting with the conversion of natural steppe into arable land during the first 'virgin lands campaign' in the late 1920s [16], it plays a key role in the world's grain production today [17]. Nearly one-third of the arable farmland in the Russian Federation is located in Siberia. Due to the short growing season in the north, arable farming is mostly concentrated in the southern part within the forest-steppe and steppe zones [18]. Cropland is located on fertile loess or loess-like sediments at the northern boundary of the Chernozem belt, mainly along the river valleys. Typical soils are leached Chernozems (Phaeozems) in the forest steppe [11]. Predominantly Chernozems and dark Kastanozems developed on fine sandy aeolian loess sediments in the steppe [19]. Arable fields in the forest steppe are typically large (several hundred ha) but surrounded and interrupted by small remnants of forest, meadows or lakes. Arable farming in Western Siberia is characterised by management practices as typical of dryland cropping with a production limit by lack of moisture [20]. Short growing seasons and high water balance deficits in summer lead to typical, fallow-based spring cereal rotations [21]. 

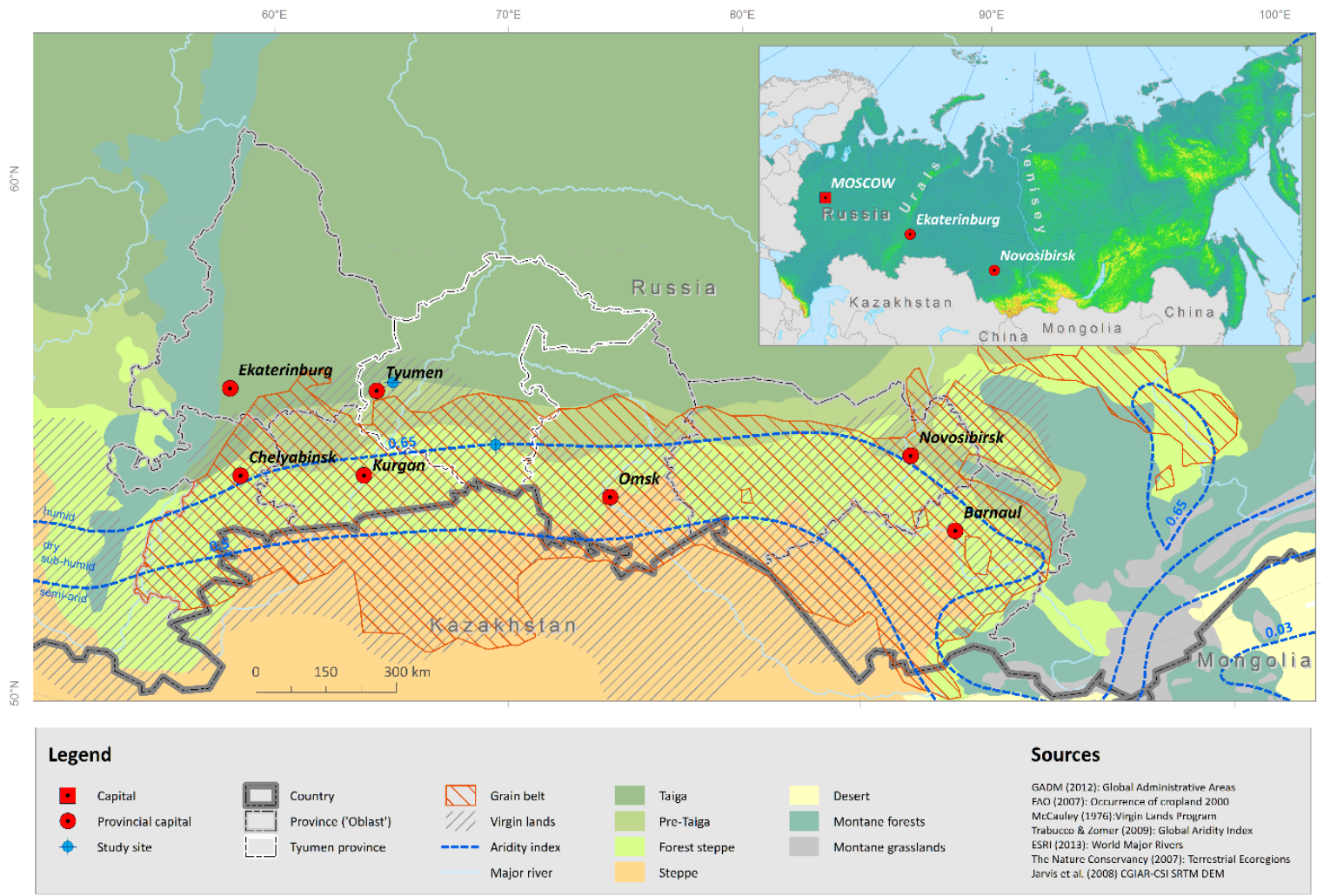

Figure 1. Location of the Western Siberian grain belt with administrative borders, vegetation zones and climate conditions. The inset map shows the flat topography of the Western Siberian plain between the Ural Mountains and the Yenisey River compared to the rest of Russia.

\section{Possible Pathways of Applied Sustainable Intensification in Western Siberia}

In 2009, when the report "Reaping the Benefits" was launched by The Royal Society, a new concept for agricultural land management was born [7]. The fundamentals of Sustainable Intensification (SI) are defined as follows: (i) utilise crop varieties and livestock breeds with a high ratio of productivity for externally and internally derived inputs; (ii) avoid the unnecessary use of external inputs; (iii) harness agro-ecological processes such as nutrient cycling, biological nitrogen fixation, allelopathy, predation and parasitism; (iv) minimise use of technologies or practices that have adverse impacts on the environment and human health; (v) make productive use of human capital in the form of knowledge and capacity to adapt and innovate and of social capital to resolve common landscape-scale or system-wide problems; (vi) minimise the impacts of system management on externalities such as greenhouse gas (GHG) emissions, clean water, carbon sequestration, biodiversity, and dispersal of pests, pathogens and weeds [7]. Since then, the concept of 'Sustainable Intensification' (SI) has been discussed frequently (e.g., [1,22-24]). Garnett et al. [2] concluded that the need for increased production should be met through higher yields rather than by cropland expansion. The necessity of this fundamental idea was underlined for Western Siberia by analyses of floral biodiversity on abandoned cropland. Results from three test areas in the Western Siberian grain belt showed already a high recovery of species rich grassland vegetation after relatively short time periods of abandonment [5]. However, the described key elements of SI are rather a goal for future agricultural practise than providing a prescription for specific agricultural techniques. The scientific community agrees about the necessity of SI in agriculture [6], nevertheless this apparent simple approach is hardly transferable into agricultural practice. Since the launch of the report by The Royal Society [7], some 1000 highly-rated papers were released, dealing with SI on different scales but mostly on a theoretic 'meta-level' as "a vaguely defined global vision" [8]. This is due, in part, to the fact that SI remains an umbrella term that 
includes many different practices and technologies, whereas the precise extent of the existing SI is difficult to estimate [9]. Further concerns about definition of SI are the possibility of very different interpretations [10]. The under-representation of the social pillar is often criticised and Loos et al. [8] request a more holistic assessment of SI against the background of global food security. Furthermore, there seems to be a competition between different terms describing the 'intensification' of agricultural development towards a more sustainable practise like 'sustainable', 'ecological', 'agro-ecological', 'socio-ecological', among others [11,12].

Practices that are often mentioned as examples for SI are conservation agriculture, organic farming, integrated pest management, agro-forestry systems, urban agriculture, or management-intensive rotational grazing systems. The most promising strategies for SI of Western Siberian agriculture are hereafter discussed.

\subsection{Substitution of Bare Fallows}

The typical dryland cropping system in Western Siberia is still a fallow-based spring cereal rotation. Common crop rotations comprise one year of summer bare fallow followed by several years of spring cereals-mainly wheat but also barley or oats.

From a historical perspective, there are several reasons to perform fallowing: conserving soil moisture, weed regulation by regular mechanical disturbance, and better nutrient mineralisation $[13,14]$. Modern cropping systems, however, showed fewer benefits since mineral fertilization and chemical weed control became the common practice in large-scale arable farming across Siberia. Therefore, the main benefit was reduced to moisture conservation, but precipitation during fallowing is known to be only partially stored for the subsquent crop [15]. Furthermore, cropland under bare fallow is prone to erosion, with substantial losses of fertile soil $[16,17]$. For this reason, the substitution of commonly performed bare fallows by cash crops would be a relevant contribution towards more efficient use of the given cropland area in Western Siberia [18,19]. In contrast, recent regional research on the performance of cropping systems (Table 1) still promotes the utilisation of bare fallow [20,21]. Mostly they concluded beneficial yield effects only for the first crop after the fallow season, not taking the fallow year without any yield into account.

Table 1. Selected results from field trials in Siberia.

\begin{tabular}{|c|c|c|c|c|}
\hline Cropping Sequence & $\begin{array}{c}\text { Average Wheat } \\
\text { Yield [t ha }{ }^{-1} \text { ] }\end{array}$ & $\begin{array}{l}\text { Average Sequence } \\
\text { Yield }\left[t \mathrm{ha}^{-1} \mathrm{a}^{-1} \text { ] }\right.\end{array}$ & Observed Years & Source \\
\hline $\begin{array}{c}\text { fallow-wheat } \\
\text { continuous wheat }\end{array}$ & $\begin{array}{c}0-2.09 \\
1.05-1.05\end{array}$ & $\begin{array}{l}1.05 \\
1.05\end{array}$ & 2013-2015 & [20] \\
\hline $\begin{array}{l}\text { fallow-wheat } \\
\text { continuous wheat }\end{array}$ & $\begin{array}{c}0-3.06 \\
1.90-1.90\end{array}$ & $\begin{array}{l}1.53 \\
1.90\end{array}$ & 2011-2014 & [21] \\
\hline
\end{tabular}

Similar findings were reported from regions with comparable agro-climatic conditions $[18,19]$, but the regional implementation is still poor. Whereas in Altai Krai, around Barnaul, various crop rotations in conjunction with reduced tillage systems are applied [22], the traditional system is still the dominant method of crop production in Tyumen region [12]. This heterogeneous distribution might be related to the extraordinary financial situation by the oil and gas industries located in the north of Tyumen region $[23,24]$.

Even more promising results were observed when replacing the fallow year with legume cops (pea, soybeans) or oilseed rape $[19,20]$. In conjunction with soil protection by reduced tillage intensity, this system of conservation agriculture is known to be beneficial in dryland cropping systems as for the Western Siberian grain belt. 


\subsection{No-Till and Conservation Agriculture}

Conservation Agriculture (CA) is a well-established agricultural practice that can enable farmers all over the world to achieve these goals of sustainable intensification [25,26]. CA is defined after FAO [27] as an "approach to managing agro-ecosystems for improved and sustained productivity, increased profits and food security while preserving and enhancing the resource base and the environment". Three strongly linked principles characterise CA, namely: (i) continuous minimum mechanical soil disturbance; (ii) permanent organic soil cover; (iii) diversification of crop species grown in sequences and/or associations [27]. Since water conservation is a key function of CA, there is high potential for implementation in dryland areas exposed to erratic and unreliable rainfall, which cover more than 2 million $\mathrm{km}^{2}$ worldwide [28]. To sustain regional and global food production, a lot of policy development aimed at promoting no-till in dryland cropping is taking place [29]. Compared to traditional, fallow-based dryland cropping systems that often run wheat monocultures, the new no-till crop rotations without fallow years provide various benefits. Better soil moisture accumulation, reduced soil losses through wind and water erosion and better soil fertility management result in a more ecological and economical land use after changing to CA in dryland regions [30].

From global meta-analyses, paired field trials conclude that no-till enables higher yields in semi-arid environments, especially for cereal crops [31]. A regional meta-study from dryland cropping trials in the Chinese Loess Plateau by Kuhn et al. [29] confirmed these advantages of no-till and highlighted that global approaches underestimate the high potential of no-till in semi-arid environments. The advantage of no-till in dryland cropping systems is even more pronounced if it is implemented within the complete CA system [32,33]. Long-term positive experiences with CA suggest that it should become the dominant practice in cereal cropping systems of steppe regions, not only in the Americas but also in Eurasia [30]. Consequently, utilization of no-till technologies and the implementation of the CA approach could help to make dryland agriculture in Western Siberia more sustainable [24,34]. Nevertheless, the current situation shows a similar distribution as the substitution of bare fallows: whereas in Northern Kazakhstan and in Altai Krai already vast areas are converted to conservational tillage, in Tyumen the traditional intensive tillage system is still dominant.

From own field trials we know the great potential for saving soil moisture by performing no-till agriculture (Figure 2). Even though the two observed growing seasons between April and October in 2014 and 2015 showed significantly cooler and wetter climate conditions compared to the long-term average (Figure 3), we observed beneficial yield effects under no-till compared to conventional tillage [35]. On average the volumetric water content in the top soil layer was higher by $40 \%$ and this led to a higher grain yield of $0.4 \mathrm{tha}^{-1}$ under no-till (Figure 4). The protein content was only slightly affected by no-till but the total protein yield (grain yield $\times$ protein content) was significantly higher $\left(0.35 \mathrm{t} \mathrm{ha}^{-1}\right)$ compared to conventional tillage $\left(0.30 \mathrm{tha}^{-1}\right)$.

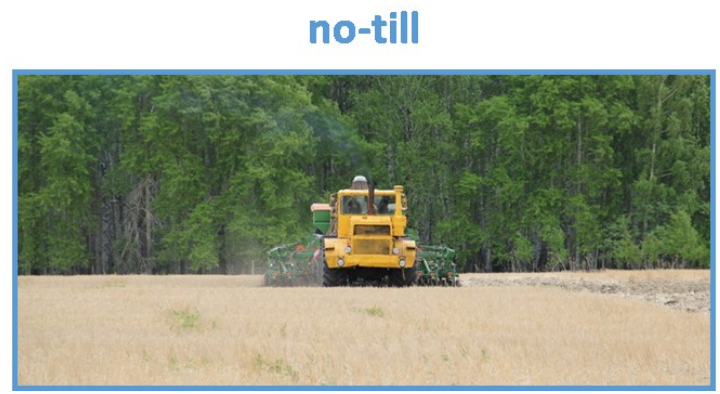

(a)

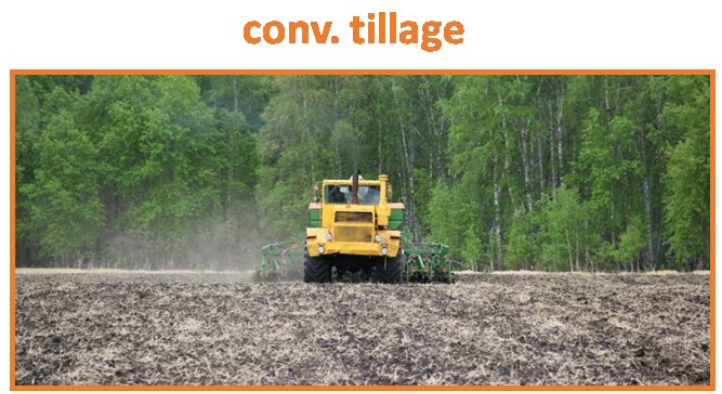

(b)

Figure 2. No-till seeding (a) compared to seeding after conventional tillage (b) with AMAZONE DMC seed drill and K700A tractor in May 2015. 


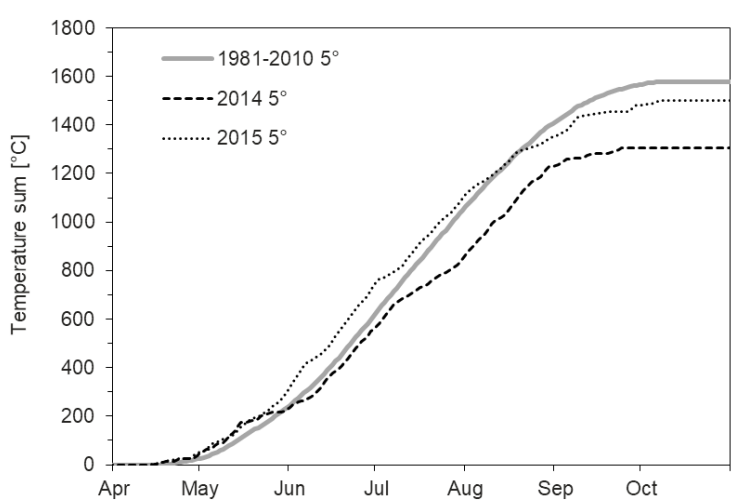

(a)

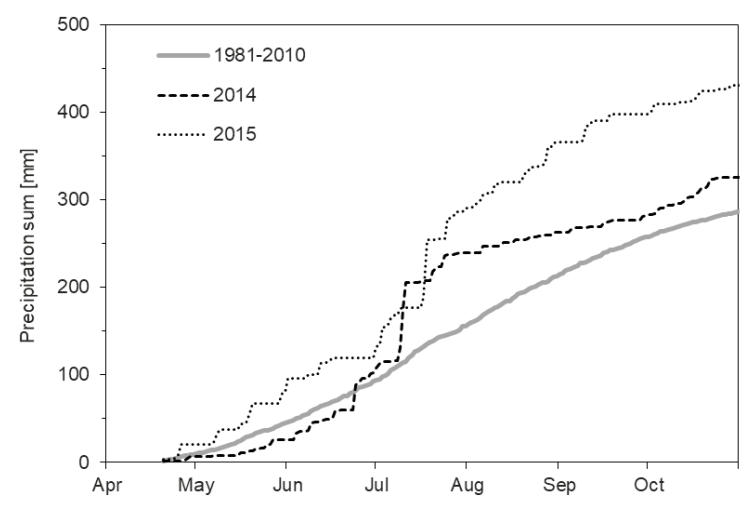

(b)

Figure 3. Cumulative temperature above $5{ }^{\circ} \mathrm{C}(\mathrm{GDD},(\mathbf{a}))$ and precipitation (b) for the two experimental years compared to the long-term average from 1981 to 2010 in Ishim. Data source: [36].

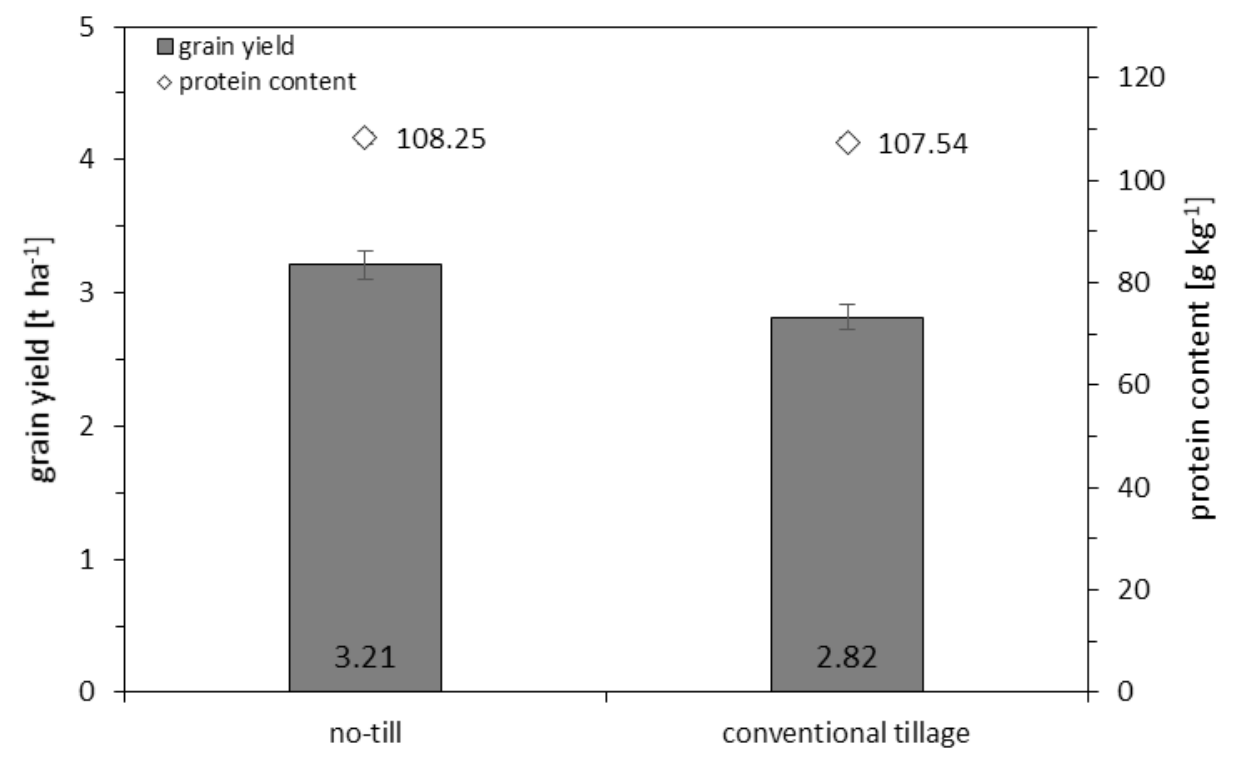

Figure 4. Average grain yield and protein content over two growing seasons. Error bars indicate 1SE of the mean $(n=24)$.

The findings of our trials revealed an overall potential for ensuring stable yields by no-till spring wheat production in Western Siberia under exceptional cold and wet conditions. Under the predicted climate change scenarios, a clearer yield effect seems to be likely [12]. Experiences from the literature reveal particularly under dry and rain-fed conditions of the continental climate zone highest potential of CA based on no-till with the possibility to increase yields [31]. Similar recent experiments in Southwestern Siberia [22] and Northern Kazakhstan [37] confirmed this general suitability for the study region.

Less tillage, however, means less mechanical weed regulation and therefore usually calls for increased use of herbicides [9,25]. Specifically for the Siberian situation such changes are expected, since the common pre-tillage weed regulation is mainly done mechanically. The adverse effects on the environment by off-site damages and herbicide resistances are not negligible and have to be balanced in an overall evaluation [32]. Giller et al. [38] ascribed the rapid expansion of no-till as key component of CA during the 1980-1990s as a combination of four factors: (i) effective herbicides were made more widely available since their release in the 1960s (atrazine, glyphosate); (ii) modern no-till seeders were able to deal with residue mulch; (iii) policy incentives supported the transition in the USA; 
(iv) the release of genetically modified (GM) crops that are resistant to post-emergence herbicides. The latter factor particularly promoted the practice of no-till on large farms in Australia, Brazil and North America. Together with the increased use of herbicides and cultivation of GM crops-often in continuous cropping or very short rotations-the weeds developed a resistance to herbicides. Since the first report on herbicide resistance in 1970, tolerances in 200 weed species have been identified with an acceleration simultaneous to the cultivation of GM varieties [32]. In particular, the repeated use of glyphosate on glyphosate-resistant GM crops lead to a widespread weed tolerance against this and became the major threat for no-till worldwide. Furthermore, the current debate about the off-site effects of glyphosate [39] demands future agronomic solutions beyond herbicide-dependent cropping systems.

Here we identified the great chance for the Western Siberian way of conservation agriculture, since the use of GM crops is restricted by law. Further diversification of Siberian crop rotations, e.g., by legumes like soy beans [40], could contribute to more pronounced advantages no-till if implemented within the CA system. Apart from this, Siberian crop production could be shaped more sustainably by better integrating with livestock systems.

\subsection{Crop-Livestock Integration}

Traditionally, agricultural education in Russia is separated between agronomy and veterinary. Even on the farms the management is usually strictly divided between the two sectors. Due to this separation there is nearly no utilisation of farm yard manure in arable farming practised [41]. Additionally, poor storage and the occasional deposition of organic manure by large-scale farms contribute to a significant amount of greenhouse gas emissions [42]. With little effort and some investment into transport and spreading equipment, the transportability of organic manure could easily be increased from currently $5-10 \mathrm{~km}$ up to $25-42 \mathrm{~km}$, calculated with given mineral fertilizer costs in 2015 [43]. A better integration of cropping and livestock systems can also contribute to the increasing nitrogen use efficiency of cropping systems [44]. Besides the resource use efficiency, from a nature conservational point of view the promotion of low-intensity grazing in Western Siberia would help to preserve biodiversity on grasslands and abandoned arable fields $[5,45,46]$. The combination of two separate strategies for SI in Western Siberia was identified as increased eco-efficiency on cropland and low-intensity grazing on grassland [47].

\section{Limitations and Trade-Offs of Sustainable Intensification}

Within the multi-layered and lively discussions about the names and meanings of 'sustainable' and 'ecological' intensification, Tittonell [48] asked the following questions: "Can intensification be sustainable without being ecological or eco-efficient" and "Is ecological intensification always sustainable?" He concluded from the current state of agricultural intensification, which is neither socially nor thermodynamically sustainable, that this intensification could not be ecological or eco-efficient [48]. Much of the debate on the words themselves is related to the differences between large-scale Western agriculture and small-holder farming in developing countries [49]. The observed damages to the environment, biodiversity losses and failures to reach the zero-hunger goal necessitate an applied dimension of SI with regionally modified strategies. Beyond all the criticism of the limits and missing clarity in the definition of SI, several authors emphasised the need for locally adapted agronomic capacity building (e.g., [32,38,48]). Following their idea of 'systems agronomy', SI is about more than just adapting principles or technologies; it explicitly calls attention to social acceptability. The described field trials aimed at an applied SI approach: together with local scientists, farm managers and machinists, some well-established ideas were jointly performed under practical conditions in Western Siberia. Therefore, the novel aspect was not the result of higher soil moisture under no-till but the first step towards convincing farmers of the necessity of managing their fields in a conservation-oriented and non-traditional way. 


\section{Conclusions}

We depicted a possible pathway of applied sustainable intensification to shape cereal production in Western Siberia and make it more water-use-efficient. However, the approach of applied SI by promoting conservation agriculture based on no-till for the Western Siberian grain belt is related to the negative concomitant effect of increased herbicide application. The success of CA worldwide is largely based on the pre-sowing application of total herbicides, mainly glyphosate. Current findings about the possible impacts of glyphosate on humans and all ecosystems require discussions about future cropping systems without boundaries. After a phase of increasingly reduced agronomic practise, a re-thinking of all agronomic instruments is necessary. Diverse crop rotations, including legumes that are adapted to changing climate conditions, would be a basis for resilient dryland cropping systems in the future.

Author Contributions: D.T. and I.K. conceived and designed the experiments; I.K. performed the experiments; S.A. performed the Russian literature review; I.K. and S.A. analysed the data; I.K. wrote the paper.

Funding: The field trial was conducted as part of project SASCHA ('Sustainable land management and adaptation strategies to climate change for the Western Siberian grain belt') funded by the German Government, Federal Ministry of Education and Research (reference 01LL0906D).

Acknowledgments: We thank A. Simerly for English language improvement and acknowledge the valuable comments of two anonymous reviewers.

Conflicts of Interest: The authors declare no conflict of interest.

\section{References}

1. Foley, J.A.; Ramankutty, N.; Brauman, K.A.; Cassidy, E.S.; Gerber, J.S.; Johnston, M.; Mueller, N.D.; O'Connell, C.; Ray, D.K.; West, P.C.; et al. Solutions for a cultivated planet. Nature 2011, 478, 337-342. [CrossRef] [PubMed]

2. Garnett, T.; Appleby, M.C.; Balmford, A.; Bateman, I.J.; Benton, T.G.; Bloomer, P.; Burlingame, B.; Dawkins, M.; Dolan, L.; Fraser, D.; et al. Sustainable intensification in agriculture: Premises and policies. Science 2013, 341, 33-34. [CrossRef] [PubMed]

3. Godfray, H.C.J.; Beddington, J.R.; Crute, I.R.; Haddad, L.; Lawrence, D.; Muir, J.F.; Pretty, J.; Robinson, S.; Thomas, S.M.; Toulmin, C. Food security: The challenge of feeding 9 billion people. Science 2010, 327, 812-818. [CrossRef] [PubMed]

4. Tilman, D.; Balzer, C.; Hill, J.; Befort, B.L. Global food demand and the sustainable intensification of agriculture. Proc. Natl. Acad. Sci. USA 2011, 108, 20260-20264. [CrossRef] [PubMed]

5. Kämpf, I.; Mathar, W.; Kuzmin, I.; Hölzel, N.; Kiehl, K. Post-Soviet recovery of grassland vegetation on abandoned fields in the forest steppe zone of Western Siberia. Biodivers. Conserv. 2016, 25, 2563-2580. [CrossRef]

6. Wezel, A.; Soboksa, G.; McClelland, S.; Delespesse, F.; Boissau, A. The blurred boundaries of ecological, sustainable, and agroecological intensification: A review. Agron. Sustain. Dev. 2015, 35, 1283-1295. [CrossRef]

7. The Royal Society. Reaping the Benefits: Science and the Sustainable Intensification of Global Agriculture; The Royal Society: London, UK, 2009.

8. Loos, J.; Abson, D.J.; Chappell, M.J.; Hanspach, J.; Mikulcak, F.; Tichit, M.; Fischer, J. Putting meaning back into "sustainable intensification". Front. Ecol. Environ. 2014, 12, 356-361. [CrossRef]

9. Pretty, J.; Bharucha, Z.P. Sustainable intensification in agricultural systems. Ann. Bot. 2014, 114, 1571-1596. [CrossRef] [PubMed]

10. Petersen, B.; Snapp, S. What is sustainable intensification? Views from experts. Land Use Policy 2015, 46, 1-10. [CrossRef]

11. Therond, O.; Duru, M.; Roger-Estrade, J.; Richard, G. A new analytical framework of farming system and agriculture model diversities. A review. Agron. Sustain. Dev. 2017, 37, 21. [CrossRef]

12. Kühling, I. Strategies for Sustainable Agricultural Land Use in Western Siberia (Russian Federation). Ph.D. Thesis, Osnabrueck University, Osnabrück, Germany, 2017.

13. Nielsen, D.C.; Vigil, M.F.; Benjamin, J.G. Evaluating decision rules for dryland rotation crop selection. Field Crop Res. 2011, 120, 254-261. [CrossRef] 
14. Campbell, C.A.; Zentner, R.P.; Gameda, S.; Blomert, B.; Wall, D.D. Production of annual crops on the Canadian prairies: Trends during 1976-1998. Can. J. Soil Sci. 2002, 82, 45-57. [CrossRef]

15. Niu, C.Y.; Musa, A.; Liu, Y. Analysis of soil moisture condition under different land uses in the arid region of Horqin sandy land, Northern China. Solid Earth 2015, 6, 1157-1167. [CrossRef]

16. Mueller, L.; Sheudshen, A.K.; Syso, A.; Barsukov, P.; Smolentseva, E.N.; Khodzher, T.; Sychev, V.G.; Romanenkov, V.A.; Rukhovich, O.V.; Puzanov, A.; et al. Land and Water Resources of Siberia, Their Functioning and Ecological State. In Novel Methods for Monitoring and Managing Land and Water Resources in Siberia; Mueller, L., Sheudshen, A.K., Eulenstein, F., Eds.; Springer: Basel, Switzerland, 2015; pp. 3-73.

17. Groisman, P.Y.; Gutman, G.; Shvidenko, A.Z.; Bergen, K.M.; Baklanov, A.A.; Stackhouse, P.W. Introduction: Regional Features of Siberia. In Regional Environmental Changes in Siberia and Their Global Consequences; Groisman, P.Y., Gutman, G., Eds.; Springer: Dordrecht, The Netherlands, 2013; pp. 1-17.

18. Suleimenov, M.; Kiyas, A.; Kaskarbayev, Z. Pulses as replacement of summer fallow in semiarid steppes of Northern Kazakhstan. Int. J. Agric. Policy Res. 2015, 3, 351-358.

19. Suleimenov, M.; Kiyas, A.; Kaskarbayev, Z. Replacement of summer fallow with oats and food legumes on black soils of Northern Kazakhstan. Asian Australas. J. Plant Sci. Biotechnol. 2010, 4, 81-86.

20. Bray, A.V.; Dronov, R.S.; Katyshev, I.N. Effektivnost' polevykh sevooborotov pri optimizatsii struktury posevnykh ploshchadey (in Russian). In Nauchnaya Diskussiya Sovremennoy Molodezhi: Aktual'nyye Voprosy, Dostizheniya I Innovatsii; AST Publishing Group: Moscow, Russia, 2015; pp. 165-168.

21. Semendyayeva, N.; Krupskaya, T.; Karlovets, L. Vliyaniye raznovidovykh sevooborotov na svoystva chernozema vyshchelochennogo Novosibirskogo priob'ya (in Russian). In Nauchno Tekhnicheskiy Progress $v$ Sel'skokhozyaystvennom Proizvodstve. Agrarnaya Nauka Sel'skokhozyaystvennomu Proizvodstvu Sibiri, Kazakhstana, Mongolii, Belarusi i Bolgarii; AST Publishing Group: Moscow, Russia, 2016; pp. 266-270.

22. Grunwald, L.-C.; Belyaev, V.I.; Hamann, M.; Illiger, P.; Stephan, E.; Bischoff, N.; Rudev, N.V.; Kozhanov, N.A.; Schmidt, G.; Frühauf, M.; et al. Modern Cropping Systems and Technologies for Soil Conservation in Siberian Agriculture. In Novel Methods for Monitoring and Managing Land and Water Resources in Siberia; Mueller, L., Sheudshen, A.K., Eulenstein, F., Eds.; Springer: Berlin, Germany, 2015; pp. 681-716.

23. Kühling, I.; Griewald, Y.; Broll, G.; Trautz, D. Potential of land-use intensity analysis for sustainable land management scenarios in southern West Siberia. Geo-Öko 2015, 36, 112-132.

24. Mueller, L.; Sheudshen, A.K.; Syso, A.; Barsukov, P.; Smolentseva, E.N.; Khodzher, T.; Sychev, V.G.; Romanenkov, V.A.; Rukhovich, O.V.; Puzanov, A.; et al. Land and Water Resources of Siberia, Their Functioning and Ecological State. In Novel Methods for Monitoring and Managing Land and Water Resources in Siberia; Mueller, L., Sheudshen, A.K., Eulenstein, F., Eds.; Springer: Berlin, Germany, 2015; pp. 3-73.

25. Hobbs, P.; Sayre, K.; Gupta, R. The role of conservation agriculture in sustainable agriculture. Philos. Trans. R. Soc. B Biol. Sci. 2008, 363, 543-555. [CrossRef] [PubMed]

26. Lal, R.; Reicosky, D.C.; Hanson, J.D. Evolution of the plow over 10,000 years and the rationale for no-till farming. Soil Tillage Res. 2007, 93, 1-12. [CrossRef]

27. Food and Agriculture Organization (FAO). What Is Conservation Agriculture? Available online: http: / / www.fao.org/ag/ca/1a.html (accessed on 13 February 2016).

28. Koohafkan, P.; Steward, B.A. Water and Cereals in Drylands; Food and Agriculture Organization: Rome, Italy, 2008.

29. Kuhn, N.J.; Hu, Y.; Bloemertz, L.; He, J.; Li, H.; Greenwood, P. Conservation tillage and sustainable intensification of agriculture: Regional vs. global benefit analysis. Agric. Ecosyst. Environ. 2016, 216, 155-165. [CrossRef]

30. Suleimenov, M.; Kaskarbayev, Z.; Akshalov, K.; Tulegenov, A. Principles of Conservation Agriculture in Continental Steppe Regions. In Novel Methods for Monitoring and Managing Land and Water Resources in Siberia; Mueller, L., Sheudshen, A.K., Eulenstein, F., Eds.; Springer: Berlin, Germany, 2015; pp. 667-679.

31. Pittelkow, C.M.; Linquist, B.A.; Lundy, M.E.; Liang, X.; van Groenigen, K.J.; Lee, J.; van Gestel, N.; Six, J.; Venterea, R.T.; van Kessel, C. When does no-till yield more? A global meta-analysis. Field Crop Res. 2015, 183, 156-168. [CrossRef]

32. Farooq, M.; Flower, K.C.; Jabran, K.; Wahid, A.; Siddique, K.H.M. Crop yield and weed management in rainfed conservation agriculture. Soil Tillage Res. 2011, 117, 172-183. [CrossRef]

33. Pittelkow, C.M.; Liang, X.; Linquist, B.A.; van Groenigen, K.J.; Lee, J.; Lundy, M.E.; van Gestel, N.; Six, J.; Venterea, R.T.; van Kessel, C. Productivity limits and potentials of the principles of conservation agriculture. Nature 2014, 517, 365-367. [CrossRef] [PubMed] 
34. Derpsch, R.; Friedrich, T.; Kassam, A.; Hongwen, L. Current status of adoption of no-till farming in the world and some of its main benefits. Int. J. Agric. Biol. Eng. 2010, 3, 1-25.

35. Kühling, I.; Redozubov, D.; Broll, G.; Trautz, D. Impact of tillage, seeding rate and seeding depth on soil moisture and dryland spring wheat yield in Western Siberia. Soil Tillage Res. 2017, 170, 43-52. [CrossRef]

36. TUTIEMPO Climate Ishim. Available online: http:/ /www.tutiempo.net/clima/ISIM/2015/285730.htm (accessed on 2 February 2016).

37. Meinel, T.; Grunwald, L.-C.; Akshalov, K. Modern Technologies for Soil Management and Conservation in Northern Kazakhstan. In Novel Measurement and Assessment Tools for Monitoring and Management of Land and Water Resources in Agricultural Landscapes of Central Asia; Mueller, L., Saparov, A., Lischeid, G., Eds.; Springer International Publishing: Cham, Switzerland, 2014; pp. 455-464.

38. Giller, K.E.; Andersson, J.A.; Corbeels, M.; Kirkegaard, J.; Mortensen, D.; Erenstein, O.; Vanlauwe, B. Beyond conservation agriculture. Front. Plant Sci. 2015, 6, 1-14. [CrossRef] [PubMed]

39. Van Bruggen, A.H.C.; He, M.M.; Shin, K.; Mai, V.; Jeong, K.C.; Finckh, M.R.; Morris, J.G. Environmental and health effects of the herbicide glyphosate. Sci. Total Environ. 2018, 616-617, 255-268. [CrossRef] [PubMed]

40. Kühling, I.; Hüsing, B.; Bome, N.; Trautz, D. Soybeans in high latitudes: Effects of Bradyrhizobium inoculation in Northwest Germany and Southern West Siberia. Org. Agric. 2017, 1-13. [CrossRef]

41. Störrle, M.; Brauckmann, H.; Broll, G. Livestock manure management in agroecosystems of southwestern Siberia, Russia. Geo-Öko 2015, 36, 133-154.

42. Störrle, M.; Brauckmann, H.-J.; Broll, G. Greenhouse gas smissions from livestock manure management in Southwestern Siberia, Russia. Sustain. Agric. Res. 2017, 6, 66. [CrossRef]

43. Störrle, M.; Brauckmann, H.; Broll, G. Working Paper 534 Wirtschaftsdünger-Rechner für Großproduzenten in der Oblast Tyumen, Russland; Universität Osnabrück: Osnabrück, Germany, 2015.

44. Lassaletta, L.; Billen, G.; Grizzetti, B.; Anglade, J.; Garnier, J. 50 year trends in nitrogen use efficiency of world cropping systems: The relationship between yield and nitrogen input to cropland. Environ. Res. Lett. 2014, 9, 105011. [CrossRef]

45. Mathar, W.P.; Kämpf, I.; Kleinebecker, T.; Kuzmin, I.; Tolstikov, A.; Tupitsin, S.; Hölzel, N. Floristic diversity of meadow steppes in the Western Siberian Plain: Effects of abiotic site conditions, management and landscape structure. Biodivers. Conserv. 2016, 25, 2361-2379. [CrossRef]

46. Weking, S.; Kämpf, I.; Mathar, W.; Hölzel, N. Effects of land use and landscape patterns on Orthoptera communities in the Western Siberian forest steppe. Biodivers. Conserv. 2016, 25, 2341-2359. [CrossRef]

47. Kühling, I.; Broll, G.; Trautz, D. Spatio-temporal analysis of agricultural land-use intensity across the Western Siberian grain belt. Sci. Total Environ. 2016, 544, 271-280. [CrossRef] [PubMed]

48. Tittonell, P. Ecological intensification of agriculture-Sustainable by nature. Curr. Opin. Environ. Sustain. 2014, 8, 53-61. [CrossRef]

49. Godfray, H.C.J. The debate over sustainable intensification. Food Secur. 2015, 7, 199-208. [CrossRef] 